\title{
A Study on Concrete Using Bottom Ash, Manufacturing Sand and Hybrid Steel and Coir Fibres
}

\author{
C. Mathiraja, \\ PG Scholar, Department of Civil Engineering, Periyar Maniammai University, Thanjavur, Tamil Nadu, India.
}

\begin{abstract}
This study in concrete is to study about hybrid combination of fibers such as corrugated steel and coir on the mechanical properties and concrete. From the compressive strength test and split tensile test carried out on 3 Nos of cube and cylinder for each trial, it was observed that compared to control mix, compressive strength increases. The increase may be due to increased availability of fibers at the micro-cracks, increase in pull out strength due to bending and warpness of fibers and improvement in bond between fiber and matrix at the interface. The presence of steel fibers in hybrid combination with coir fiber has improved post-cracking behavior of the beam specimens.
\end{abstract}

Keywords: Bottom Ash, Manufacturing Sand, steel fibre and coir fibre

\section{Introduction}

The inclusion of fibers into concrete not only provides considerably more ductile structure but also improves such structural properties as tensile strength, static flexural strength, impact strength, flexural toughness and the energy absorption capacity of the high strength concrete. Steel fibre has a considerably larger length and higher Young's modulus of elasticity as compared to the other fibre-types. This leads to an improved flexural rigidity and has great potential for crack control, although the volumetric density is high. It is also important to note that steel is conductive in both electric and magnetic fields and hence, the steel fiber content has to be reduced to a certain level. Optimization of mechanical and conductivity properties can be achieved by combining different types of fibres, such as in the case of natural fibres ( coir, sisal, and palm fibre and steel fiber). The attractive advantage of hybrid fibres system is that it provides a system in which one type of fiber, which is stronger and stiffer, improves the first crack stress and ultimate strength, where the second type of fibre, which is more flexible and ductile, leads to the improved toughness and strain capacity in the postcracking zone. It also contributes to a hybrid reinforcement, in which the smaller fibre bridges microcracks and reduce crack widths. This leads to a higher tensile strength of the composite. The second type of fiber is larger, so that it can arrest the propagating macrocracks and can substantially improve the toughness of the composite. However, most of the research work and utilization of fibre reinforcement are about monotype fiber. Using hybrid fibres as reinforcement to improve the performance of concrete are not frequently reported. Therefore, the research would present the results of some properties of high strength concrete added with hybrid fibres.

\section{Materials And Experimental Methods}

Ordinary Portland cement conforming to IS 12269-1987 has been used for making the concrete mixtures. The fine aggregate used was river sand conforming to IS 383-1970, has specific gravity of 2.55 and fineness modulus of 2.93.The crushed granite having specific gravity of 2.68 is used as coarse aggregate. The details of the mix proportions used are given in Table. M20 grade of concrete was used.

\section{A. Cement}

\begin{tabular}{|l|l|}
\hline \multicolumn{2}{|c|}{ Fibre Properties } \\
\hline \multicolumn{1}{|c|}{ Steel Fiber } & \multicolumn{1}{c|}{ Coir Fiber } \\
\hline $\begin{array}{l}\text { Average fiber length }(\mathrm{mm})=50 \text {, Diameter } \\
(\mathrm{mm})=1, \text { Aspect ratio }=50\end{array}$ & Average fiber length $(\mathrm{mm})=50$ \\
\hline
\end{tabular}

Ordinary Portland Cement of grade - 53 conforming to Indian standard IS: 12269-1987 has been used in the present study. The physical and chemical properties are given in Table.

\begin{tabular}{|c|c|l|c|}
\hline \multicolumn{4}{|c|}{ Requirements as per IS12269-1987 } \\
\hline \multicolumn{2}{|c|}{ Physical Properties } & \multicolumn{2}{c|}{ Chemical Properties } \\
\hline 1. Fineness & $225(\mathrm{~min})$ & 1. Lime saturation factor & $.8-1.02$ \\
\hline 2. Setting time & 2. Alumina Modulus & $.66(\mathrm{~min})$ \\
\hline Initial (min) & 30 minutes & 3. Insoluble residue (\%) & $4(\max )$ \\
\hline Final (max) & 600 minutes & 4. Magnesia (\%) & $6(\max )$ \\
\hline & & 5. Sulphuric anhydride (\%) & $3(\max )$ \\
\hline & & 6. Loss on ignition (\%) & 4 (max) \\
\hline & & 7. Chloride (\%) & $.1(\max )$ \\
\hline
\end{tabular}


B. Bottom Ash

\begin{tabular}{|l|l|c|c|}
\hline \multicolumn{2}{|c|}{ Physical Properties } & \multicolumn{2}{c|}{ Chemical Properties } \\
\hline Colour & Whitish gray to gray with slight black & Silica $\left(\mathrm{SiO}_{2}\right)$ & $40-79$ \\
\hline Bulk density & $1120 \mathrm{~kg} / \mathrm{m}^{2}$ & Alumina( $\left(\mathrm{Al}_{2} \mathrm{O}_{3}\right)$ & $23-33$ \\
\hline Specific gravity & $2.14-2.42$ & Ferric Oxide $\left(\mathrm{Fe}_{2} \mathrm{O}_{3}\right)$ & $0.6-4$ \\
\hline Fineness & $2800-3200 \mathrm{~cm}^{2} / \mathrm{gm}$ & Calcium Oxide $(\mathrm{CaO})$ & $2.8-20$ \\
\hline & & Magnesia $(\mathrm{MgO})$ & $1.5-5.0$ \\
\hline & & Lgnition loss & $1.0 \quad-3.0$ \\
\hline
\end{tabular}

\section{Fine aggregate}

Locally available sand has been used as fine aggregate. In this study it was used the sand of Zone-II, known from the sieve analysis using different sieve sizes $(10 \mathrm{~mm}, 4.75 \mathrm{~mm}, 2.36 \mathrm{~mm}, 1.18 \mathrm{~mm}, 600 \mu \mathrm{m}, 300 \mu \mathrm{m}$, $150 \mu \mathrm{m}$ ) adopting IS 383:1963.

\begin{tabular}{|c|c|}
\hline Sieve size & Percentage of passing \\
\hline $10 \mathrm{~mm}$ & 100 \\
\hline $4075 \mathrm{~mm}$ & $90-100$ \\
\hline $2.36 \mathrm{~mm}$ & $75-100$ \\
\hline $1.18 \mathrm{~mm}$ & $55-90$ \\
\hline $600 \mu \mathrm{m}$ & $35-59$ \\
\hline $300 \mu \mathrm{m}$ & Aug-30 \\
\hline $150 \mu \mathrm{m}$ & $0-10$ \\
\hline
\end{tabular}

\section{Manufacturing Sand}

\begin{tabular}{|c|c|c|}
\hline Manufacturing Sand & \multicolumn{2}{|c|}{$\begin{array}{l}\text { M-sand is crushed aggregates produced from hard granite stone whic } \\
\text { edges, washed and graded with consistency to be used as a substitute }\end{array}$} \\
\hline \multicolumn{3}{|l|}{ E. Coarse Aggregate } \\
\hline & $\begin{array}{l}\text { Coarse } \\
\text { Aggregate }\end{array}$ & $\begin{array}{l}12 \text { to } 20 \mathrm{~mm} \\
\text { size }\end{array}$ \\
\hline \multicolumn{3}{|l|}{ F. Fibres } \\
\hline & \multicolumn{2}{|c|}{ Steel fibre } \\
\hline & \multicolumn{2}{|c|}{$\begin{array}{l}\text { Two types - corrugated and hooked types having } \\
\text { Aspect ratio }=50 \text { (Length } 50 \mathrm{~mm} \text {, diameter } 1 \mathrm{~mm})\end{array}$} \\
\hline
\end{tabular}

\section{Casting Details}

The required materials for preparing the concrete were weighed as per the required proportions. The cement and bottom ash were thoroughly mixed in the dry state, and the sand with m.sand was added later to the mixture. The mixture was again thoroughly mixed and gently placed over the coarse aggregate. In case of fiber reinforced concrete, fibers were evenly sprinkled during the mixing. Water was finally added to the dry mixture. Mixing was carried out until a workable mixture was obtained. The entire mixing was carried out on a dry platform. Concreting was done in the moulds while they were on a platform vibrator. Vibrations were continued for one minute to ensure uniform compaction. The specimens were demoulded after 24 hours of casting and placed in a curing tank for 28 days. After the curing period, the specimens were removed from the curing tank and whitewashed for better visibility of cracks. The specimens as IS standards were prepared: $150 \mathrm{~mm}$ cubes for compressive strength as per IS 516 - 1999, $100 \times 300 \mathrm{~mm}$ cylinders for split tensile strength as per IS 5816 1999

\section{Mix Ratio}

\begin{tabular}{|c|c|c|c|c|c|c|c|}
\hline S.No. & \multirow{2}{*}{$\begin{array}{c}\text { Cement } \\
\left(\mathrm{kg} / \mathrm{m}^{3}\right)\end{array}$} & $\begin{array}{c}\text { Bottom } \\
\text { Ash } \\
\left(\mathrm{kg} / \mathrm{m}^{3}\right)\end{array}$ & $\begin{array}{c}\text { Aggregate } \\
\left(\mathrm{kg} / \mathrm{m}^{3}\right)\end{array}$ & $\begin{array}{c}\text { M.Sand } \\
\left(\mathrm{kg} / \mathrm{m}^{3}\right)\end{array}$ & $\begin{array}{c}\text { Coarse } \\
\text { Aggregate } \\
\left(\mathrm{kg} / \mathrm{m}^{3}\right)\end{array}$ & \multicolumn{2}{|c|}{ Fibres } \\
\hline CM1 & 320 & - & 822 & - & 990 & - & - \\
\hline CM2 & 256 & 64 & 205.5 & 616.5 & 990 & 1.0 & - \\
\hline CM3 & 256 & 64 & 205.5 & 616.5 & 990 & - & 1.0 \\
\hline CM4 & 256 & 64 & 205.5 & 616.5 & 990 & 0.5 & 0.5 \\
\hline CM5 & 256 & 64 & 205.5 & 616.5 & 990 & 0.75 & 0.25 \\
\hline CM6 & 256 & 64 & 205.5 & 616.5 & 990 & 1.25 & 0.5 \\
\hline
\end{tabular}




\section{Testing}

The compressive strength test on cube specimens at 28 days splitting tensile strength test on cylinder specimens at 28 days were carried out using universal testing machine of capacity of 100tones. For the compressive strength test, load was applied gradually at the rate of $140 \mathrm{~kg} / \mathrm{cm}^{2}$ per minute till the specimens fails. During the Splitting tensile strength test, the load was applied continuously without shock at a rate of approximately $18 \mathrm{~kg} / \mathrm{cm}^{2} /$ minute.

\section{Results}

The results obtained from the compressive strength test and split tensile strength test are given in Table.

\begin{tabular}{|c|c|c|}
\hline Mix Id & $\begin{array}{c}\text { 28 days Compressive } \\
\text { Strength, mPa }\end{array}$ & $\begin{array}{c}\text { Split tensile Strength, } \\
\mathrm{mPa}\end{array}$ \\
\hline CM1 & 24.36 & 2.02 \\
\hline CM2 & 27.81 & 4.27 \\
\hline CM3 & 26.43 & 4.10 \\
\hline CM4 & 28,01 & 3.92 \\
\hline CM5 & 30.12 & 4.29 \\
\hline CM6 & 34.13 & 5.11 \\
\hline
\end{tabular}

\section{Conclusion}

From the study conducted to examine the role of fibers of both metallic and coir fibre types on the compressive strength, split tensile strength of concrete specimens when added in different hybrid combinations, the following conclusions can be stated. Compared to performance of Mono-fiber added concrete element, hybrid fiber added concrete is found to be appreciable due to the reason that high modulus fibers tend to increase strength with only modest improvement in toughness, while low modulus fibers tend to increase the toughness with little or no improvement in strength. The highest splitting tensile strength to an extent of gradually increases.

\section{References}

[1] N. Banthia, A. Bentur and A. Mufti (1998) Fiber Reinforced Concrete: Present and Future, (Canadian Society of Civil Engineering), Montreal, 64-97.

[2] A.Sivakumar and Manu Santhanam (2007) Mechanical properties of high strength concrete reinforced with metallic and non metallic fibres, Cement and Concrete Composites, $29603-608$.

[3] Nicolas Ali Libre, Mohammad, Mehrdad and Parviz, (2011) Mechanical Properties of hybrid fiber reinforced light weight aggregate concrete made with natural pumice", Construction and Building Materials 25 2458-2464.

[4] C.X.Qian and P.Stroeven, (2000) Development of Hybrid Polypropylene - steel fibre - reinforced concrete", Cement and concrete research, 30, 63-69.

[5] Majid Ali, Anthony Liu, Hou Sou, Nawawi Chouw, "Mechanical and dynamic properties of coconut fibre reinforced concrete", Construction and Building Materials 30 ,2012, 814-825

[6] Romildo Dias Tolêdo Filho, Kuruvilla Joseph, Khosrow Ghavami \& George Leslie England, "The use of sisal fibre as reinforcement in cement based composites", Revista Brasileira de Engenharia Agrícola e Ambiental, v.3, n.2, 1999, 245-256 